\title{
English for Russian scientific purposes: tips to improve word use
}

\author{
Dmitry Tychinin \\ Institute of Biochemistry and Physiology of Plants and Microorganisms, Russian Academy of Sciences (IBPPM RAS), \\ Saratov, Russia; tychinin_d@ibppm.ru,dmitry.tychinin@mail.ru
}

DOI: 10.20316/ESE.2018.44.17023

\begin{abstract}
Worldwide dissemination of Russian science is impeded by scientists' poor written English. A first step to better English is to cleanse manuscripts of faulty words. The faults discussed in this article are the overuse of active(ly), create, due to, etc, preparation, and study, as well as the misuse of allow, approbate, register, and scientific work(s). The discussion ends with a brief message to the Russian author.
\end{abstract}

Keywords: English, Russian, word misuse, word overuse

\section{Introduction}

Russian scientists can reach broader audiences by publishing in English, the scientific lingua franca. But success in international publication depends largely on the ability to write good English - an ability hard to master for many Russians.

This essay focuses on how native Russian speakers can avoid overusing and misusing some English words and phrases. Russians' problems with English words are not confined to those pointed out here. For more examples, the reader is directed to the QC [Quality Control] Memos from the translation service of MAIK Nauka/Interperiodica, a leading Russian academic publisher. ${ }^{1}$ In the notes that follow, I was careful not to repeat the material presented in those memos.

My examples came from two sources. One source was randomly chosen Russian bioscience and ecoscience articles published between 1994 and 2017 in the English versions of domestic journals or in foreign Englishlanguage journals. The other source was manuscripts brought to me for language editing by research staff at my institute of employment. All examples were edited for length and clarity. Russian words were transliterated online (www.translit.net) by using the Library of Congress system.

\section{Dictionaries}

I consulted Webster's Ninth New Collegiate Dictionary ${ }^{2}$ for the meanings of English words and SA Kuznetsov's The Large Explanatory Dictionary of the Russian Language ${ }^{3}$ for the meanings of Russian words. Both dictionaries are extensive and the word definitions are detailed. Webster's Ninth has entries for usage and synonyms, and Kuznetsov's dictionary has numerous examples of phrases and sentences illustrating correct Russian usage.

\section{Problems and remedies}

Active(ly)

If the use of active and actively becomes too frequent in a paper, consider looking for replacements or rewording the sentences. Some examples and their possible revisions:
- active bacterial growth $\rightarrow$ vigorous (or: intense) bacterial growth

- $\quad$ an active producer of arachidonic acid $\rightarrow$ a vigorous (or: a strong) producer of arachidonic acid

- cells were actively moving $\rightarrow$ cells were moving well

- grew actively on $\rightarrow$ grew well on

- have been actively studied $\rightarrow$ have received much study

- have been actively used $\rightarrow$ have been used widely (or: extensively)

- $\quad$ the most active degrader of aviation fuel $\rightarrow$ the most potent degrader of aviation fuel

Allow

Pozvoliat', the Russian for allow, does not need a direct object. Thus, eti dannye pozvoliaiut predpolozhit' (these data allow to suggest) is as correct as eti dannye pozvoliaiut nam predpolozhit' (these data allow us to suggest). In English, a direct object (one, us, them, the researchers, etc) is essential. One, however, is a rather stilted word and should be used sparingly.

It is also possible to nominalise the verb denoting what is allowed (these data allow the suggestion that ...) or to take advantage of the passive (... allow the suggestion to be made that...).

\section{Approbate, approbation}

The Russian aprobatsiia and the English approbation do not correspond one to one. According to Kuznetsov's dictionary, aprobatsiia has two meanings: "official approval or sanction based on a check or test" and, in agriculture, "evaluation of the varietal qualities of crops and plantings to ascertain the suitability of their yield for use as seed" (translations mine). The English approbation has three meanings: one obsolete ("proof") and the other two current ("an act of approving formally or officially" and "commendation or praise"). Therefore, the two words convey somewhat different things. Despite that, the verb aprobirovat' - used widely in scientific Russian to mean "test the performance or effect of" - is often mistranslated as approbate. In all the examples below, approbate should have been replaced by test:

- the engineering performance of the spectrometer was approbated

- the nonhydrostatic model of sea dynamics was approbated

- the technology was approbated at the Prioksky sludge recycling center

\section{Create, creation}

Wherever you can, change create and creation to something less pompous. Although in a Russian paper a phrase such as sozdanie vaktsin (the creation of vaccines) might be acceptable, in English vaccines are designed or developed. 
Likewise, biosensors are built, constructed, or made; conditions are established or set; and websites are organised or set up. The choice is rich, so you can do without create.

\section{Due to}

Russians have a penchant for due to because it is frequent in native English writing and because it seems to work in all positions in a sentence. But, as noted by Greenbaum and Whitcut, ${ }^{4}$ due to is perfectly acceptable only when used after linking verbs (the error was due to negligence) or immediately after a noun (no changes due to erosion were observed; examples mine). Outside these positions, it is safer to use owing to or because (of), or rephrase:

- actively used due to their relatively low cost $\rightarrow$ actively used owing to ... (or: ... because their cost is relatively low)

- $\quad$ all attempts have proven unsuccessful, supposedly due to the lethality of this mutation $\rightarrow$... supposedly because of ...

- Due to the high contagiousness of this disease, these patients present a significant hazard $\rightarrow$ Because this disease is highly contagious, ...

Due to the fact that, which too is widespread among English-speaking Russians, can be simplified to because: ${ }^{5}$

- $\quad$ preference is given to colloidal gold due to the fact that it has the lowest cytotoxicity among $\ldots \rightarrow$ colloidal gold is preferred because its cytotoxicity is the lowest among ... (or even: ... because of its low cytotoxicity)

\section{Etc}

Et cetera (and so forth), abbreviated as etc, is best reserved for parenthetical lists: (hormones, vitamins, antibiotics, etc). But bear in mind that heavy use of etc makes the writing imprecise, suggesting that the authors are either careless or unsure what else to list. In text, etc has no place and should be revised as exemplified below:

- detected with the use of visual observations, lightscattering methods, vibrational spectroscopy, etc $\rightarrow$ detected by visual observations and by methods such as light scattering and vibrational spectroscopy

- for the detection of biomolecules and microorganisms, for the design of DNA chips, etc $\rightarrow$ for purposes including the detection of biomolecules and microorganisms and the design of DNA chips

- $\quad$ urine, blood, saliva, etc $\rightarrow$ urine, blood, saliva, and other bodily fluids

\section{Preparation}

In the sense of "something that is prepared", preparation (Russian: preparat) is overused by Russians. It is also a vague word, and the editor may ask for more specific substitutes. Depending on what kind of preparation you have in mind, you may choose product, sample, inoculant, mixture, or even fertiliser, herbicide, and drug. Some examples:

- a bacterial preparation was applied $\rightarrow$ a bacterial inoculant was applied

- a commercial preparation of silver oxide $\rightarrow$ a commercial silver oxide product
- $\quad$ preparations of plant DNA were analysed $\rightarrow$ samples of plant DNA were analysed

- the commercial preparation "Radogor" was used $\rightarrow$ the commercial fertiliser Radogor was used

One more substitute for preparation is formulation:

- the commercial preparation "Radogor" was used $\rightarrow$ the commercial formulation Radogor was used

- vaccine preparations $\rightarrow$ vaccine formulations

\section{Register}

Is a change registered or recorded? Either is possible. If the change is entered in a register, then it is registered. But if it is detected with a scientific instrument, it is recorded:

- absorption spectra were registered using a spectrophotometer $\rightarrow \ldots$ were recorded with a spectrophotometer

- soil temperature was registered with the help of temperature loggers $\rightarrow$... was recorded with temperature loggers

Record is not the only choice. Spectra are taken, temperatures are measured - and differences are found, as revised below:

- The most striking differences were registered in the first generation $\rightarrow \ldots$ were found in the first generation (or simply: ... were in the first generation)

The misuse of register for record is shared by Russians with Norwegians $^{6}$ and is caused by native language interference (the Russian for register is registrirovat').

\section{Scientific work(s)}

Native English speakers use work synonymously with research: Work by Smith and others has shown that ... In the sense of "a study, an article", work is popular with "exact" scientists, such as physicists or mathematicians: as reported in the work [5]. Scientific works appropriately refers to papers and books by an eminent scientist: the scientific works of Academician LD Landau. Beyond these contexts, (scientific) work(s) sounds odd to mother-tongue English speakers. Therefore, opt for articles, studies, reports, or research instead:

- $\quad$ investigated in a series of works $\rightarrow$ investigated in a series of reports

- $\quad$ some works recently carried out $\rightarrow$ some recent studies

- $\mathrm{X}$ has been described in many scientific works $\rightarrow$... in many articles (Or: Much research has described X ...)

Study (v.)

To avoid overuse of study, try examine, investigate, or test:

- $\quad$ all of the studied bacterial strains accumulated lipids $\rightarrow$ all the strains examined (or: tested) accumulated lipids (The strains were examined for their ability to accumulate lipids, and lipid accumulation was studied).

- $\quad$ associative symbioses have been studied for only two decades $\rightarrow \ldots$ have been investigated...

- in the present paper, the nature of the immune response was not studied in detail $\rightarrow$ in this paper, the immune response was not examined in detail

Do not forget the somewhat verbose but idiomatic phrases 
used (or: included) in this study and chosen for study:

- $\quad$ soils from the lysimeters were the objects studied in this work $\rightarrow$ soils from the lysimeters were used in this study (or: were chosen for study)

Study is often not needed and can be omitted:

- all of the studied bacterial strains accumulated lipids $\rightarrow$ all the strains accumulated lipids

- calluses were formed in all media studied $\rightarrow \ldots$ in all the media (The authors did not study the media; rather, they used them to study callus formation.)

- these strains [of E. coli] were sensitive to the studied phage $\rightarrow \ldots$ were sensitive to the phage (The phage was not studied; rather, it was used to test the phage sensitivity of E. coli).

Finally, there is the common cliché study the possibility of. It too can be improved with examine or test. But a complete rewrite is even better:

- the aim of the present investigation was to study the possibility of $\ldots \rightarrow$ here we examine (or: ask, test) whether it is possible to ...

\section{Message to the Russian author}

To minimise word misuse and overuse:

1. Do not translate literally.

2. Do not use free online services to make translations. If you are unskilled in English, seek help from a language professional or from a competent colleague.

3. Do not copy and paste material from others' papers. That is a sure way to infect your prose with all sorts of errors, linguistic and scientific. In addition, you may be accused of being a plagiarist.
4. Consult an explanatory English dictionary and a thesaurus (a dictionary of synonyms and antonyms). Both are easy to find on the Web (eg Merriam-Webster Online, www.merriam-webster.com).

5. Consult a usage guide. Sadly, such books are rare in Russia. A time tested guidebook to (primarily British) English usage is Greenbaum and Whitcut's Longman Guide to English Usage, published in Russia in $1990 .{ }^{4}$ For a comprehensive treatment of word usage in scientific English writing, I wholeheartedly recommend the fourth edition of Goodman et als Medical Writing - A Prescription for Clarity. ${ }^{6}$ This book is not available in Russia but can be ordered online.

\section{Acknowledgement}

I thank the anonymous reviewer for his or her valuable help in revising the manuscript.

\section{References}

1 MAIK Nauka/Interperiodica. QC Memos. Available at: http://www. maik.ru/ru/translation/qc-memos/ (accessed 11 October 2017).

2 Webster's Ninth New Collegiate Dictionary. Springfield, MA; MerriamWebster, 1987.

3 Kuznetsov SA. Bol'shoi tolkovyi slovar' russkogo iazyka [The Large Explanatory Dictionary of the Russian Language]. St. Petersburg; Norint, 2000.

4 Greenbaum S, Whitcut J. Longman Guide to English Usage, Special edition. Moscow; Russky Yazyk, 1990.

5 [EASE] European Association of Science Editors. 2017. EASE Guidelines for Authors and Translators of Scientific Articles to be Published in English. European Science Editing 43(4):e1-e16. doi:10.20316/ESE.2017.43.e1 6 Goodman NW, Edwards MB, Langdon-Neuner E. Medical Writing - A Prescription for Clarity, 4th edition. Cambridge; Cambridge University Press, 2014.

\section{Reaching out in Romania}

One activity in the chain of events organised by EASE around the conference in Bucharest, was the Scientific Writing Workshop held at the Ovidius University, Constanta, on June 12, 2018. It was prepared and led by Eva Baranyiová and contained presentations on scientific communication, manuscript preparation, ethical issues and preparation of references. There were also materials prepared for a hands-on experience but unfortunately this part could not be done as originally planned because of time contraints - the
20 participants (pictured below) were mostly young medical doctors. The workshop was opened by Vice-Rector, Professor Mihai Girtu and locally organised by Professor Alina Buzatu. Discussions during the workshop were vivid and interesting. The participants obtained pdfs of the presented materials to help them in their future work.. The workshop was viewed as important - at its end even the Rector, Professor Sorin Rugina came to shake hands with nice words of appreciation.

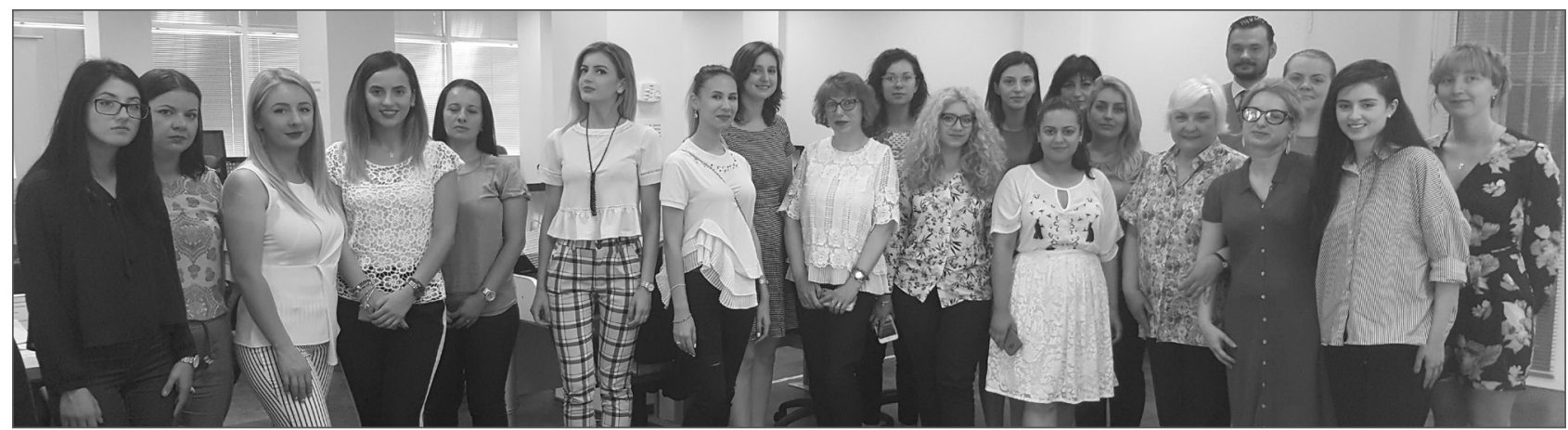

